\title{
Holding on to the Past: Southern British Evidence for Mummification and Retention of the Dead in the Chalcolithic and Bronze Age
}

\author{
Martin J. SMITH ${ }^{1}$, Michael J. ALLEN ${ }^{2}$, Gabrielle DELBARRE ${ }^{1,}$ Thomas BOOTH $^{3}$, Paul \\ CHEETHAM $^{1}$, Lauren BAILEY ${ }^{1}$, Francine O'MALLEY ${ }^{4}$, Mike PARKER PEARSON ${ }^{5}$ and \\ Martin GREEN ${ }^{6}$. \\ ${ }^{1}$ Bournemouth University, Christchurch House C134, Talbot Campus, Fern Barrow, Poole, \\ BH12 5BB; UK \\ ${ }^{2}$ Allen Environmental Archaeology, Redroof, Green Road, Codford, Wiltshire, BA12 0NW, \\ UK; \\ ${ }^{3}$ Natural History Museum, Cromwell Road, London, SW7 5BD, UK; \\ ${ }^{4}$ University of Southampton, University Road, Southampton, SO1 1BJ, UK \\ ${ }^{5}$ UCL Institute of Archaeology, 31-34 Gordon Square, London WC1H OPY, UK; \\ ${ }^{6}$ Cranborne Chase Archaeology, Down Farm, Sixpenny Handley, Dorset, SP5 5RY, UK.
}

\begin{abstract}
Recent treatments of burial practices in prehistoric Europe have tended to emphasise the variety of practices that are apparent in any given period; contra previous views which tended to emphasise homogeneity over time. In the spirit of more recent considerations that emphasise a more holistic approach, the current article presents investigations of human remains interred within and around a single monument at Cranborne Chase, Dorset, UK. By taking a synthetic approach giving equal weight to taphonomy, archaeothanatology, histological analysis, scanning electron microscopy, micro-CT scanning, experimentation and contextual dating, a more nuanced picture has been revealed, where the dead were dealt with in ways that were both more complex and considerably more protracted than might otherwise be assumed. In particular, several lines of evidence point to practices aimed at the protracted curation of the dead as articulated bodies with at least some soft tissue persisting. This observation is of particular importance in light of previously published claims for 'mummification' in Bronze Age Britain. It suggests that such practices may have been both widespread and persistent over time.
\end{abstract}

\subsection{Introduction}

\subsection{Traces of a Monument}

Cranborne Chase is an area of open chalk downland situated in central southern England with a rich and varied selection of well-preserved prehistoric remains and a long history of archaeological study. An area encapsulated by two modern farms, Down Farm and adjacent Canada Farm (Fig. 1b) is among the most comprehensively investigated parts of the landscape, containing a broad range of monuments, burials and occupation evidence stretching from the Mesolithic to the Romano-British period and beyond (Barrett et al. 1991a,b; Green and Allen, 1997; Green 2000; French et al., 2007). During the early part of one of the author's (MG) fieldwalking surveys of the upper Allen valley in Cranborne Chase in 1972 the soil mark of a plough-flattened barrow was recorded on Canada Farm (Fig. 1). This feature lay approximately 20 metres north of the Dorset Cursus (the longest prehistoric monument in Britain at approximately 10km). In 2007 the featured was identified again by a fluxgate gradiometer survey (by PC) which revealed a section of the enclosing ditch and 
additionally a large central anomaly interpreted as a possible grave pit (Fig 1c). Due to the continuing plough-induced erosion of the area a decision was made to excavate, with the resulting work taking place in 2009 and an interim report following in 2012 (Green, in Jones et al. 2012). The excavations uncovered two phases of ditch which partly impinged on one another. The first phase ditch consisted of a penannular ring with a diameter of 13 metres with a 4 metre wide gap to the west, partly filled by an elongated pit (F7). The ditch was about 1 metre wide with an average depth of $0.4 \mathrm{~m}$. The inner ditch was also penannular in shape with a metre wide gap to the southwest and of a similar width -with an overall diameter of 11.5 metres. The surviving depth was only $0.1 \mathrm{~m}$ revealing plough truncation, which accounted for the poor geophysical response. Ground penetrating radar, electromagnetic and earth resistance surveys failed to reveal additional detail. A structure consisting of nine postholes lay just outside the ditches to the northwest but remains to be dated.

\subsection{Successive Inhumations}

Enclosed within the ditches were two cut features, F1, a large central (apparently) Beaker period inhumation associated with the phase 1 ditch, and F2, an elongated pit which contained a small Beaker but no surviving human remains, probably due to the acidic nature of the clay fill. Five satellite interments, dating from the Middle Bronze Age (see below) were found cut into the ditches with a sixth outside to the southeast (F3). Of these, two contracted inhumations (F4, F5) were cut into the southeastern terminal of the phase 2 ditch with a further cutting the southern terminal of the phase 1 ditch (F8). This latter grave was found at the base of the plough soil and clearly would soon have been ploughed away if the excavations had not intervened. The remaining interments comprised a flexed infant (F6) and a cremation $(\mathrm{C} 1)$, both cutting the intersecting ditches on the southeast side.

Taken at face value the Canada Farm inhumations seem relatively straightforward and unremarkable in themselves as essentially 'standard' examples of the funerary practices of their respective dates. However, on further investigation, anomalous features became apparent with regard to three of the burials, which could not easily be explained. The radiocarbon dates obtained from $\mathrm{F} 1$ were inconsistent with the accepted date range of the accompanying Beaker (see below). Two of the satellite inhumations, F3 and F5 exhibited anthropogenic modifications of several bones which could only have been produced some time after death and implied that these apparently straightforward articulated inhumations had undergone some degree of disarticulation followed by re-assembly. Taken together these burials implied mortuary practices that are both more complex and more protracted than is generally assumed at these dates, and which hold further significance in relation to claims made for similarly drawn out and multi-faceted funerary treatments elsewhere in Bronze Age Britain. The current article presents the results of additional analysis using a range of different techniques applied in order to resolve and further investigate these anomalies.

\subsection{The Human Remains (MS, GD, FO and $L B$ )}

\subsection{The Central Inhumation}

The central grave incorporated a $5 \mathrm{~cm}$-deep recess, which may originally have held a rectangular, wooden coffin. The recess had been dug into the bedrock floor of a larger burial pit ( $2.6 \times 2 \times 0.45 \mathrm{~m}$ deep), which had then been in-filled with rubble. The grave contained an adult male aged 25-30 years, accompanied by a Wessex/Middle Rhine Beaker, a weathered antler toggle and slivers from a boar's tusk. The body was interred in a semi-flexed position, 
on his left side facing the east (Fig. 2a). While the body had been predominantly articulated when buried, the mandible was no longer in articulation and was located in the northwest corner of the presumed coffin. The right upper limb was also slightly displaced at both the shoulder and elbow joints whilst the bones of the left were disarticulated but resting in positions consistent with having been originally articulated in a flexed position. These dislocations may suggest the individual either to have been dead for some time at the point of burial with at least some soft tissues having decayed, or to have been subject to disturbance some time later. Further suggestions that the body was not interred immediately after death were present in the form of damage consistent with mammalian scavenging. This comprised furrowing at the articular ends of long bones and crenulation on the iliac crests. These patterns of damage are consistent with the actions of canids (Binford, 1981; Smith, 2006), most likely either wolves or possibly foxes, or otherwise domestic dogs. However, the lack of other recognised types of canid induced damage (pitting, puncturing and scoring) suggests the respective scavengers did not have access to the body for an extended period. Scavenging by canids has been observed to follow a predictable sequence (Haglund, 1997). In this case the damage present was consistent with the body being accessible to scavengers for a period of weeks rather than months.

This individual produced two AMS dates calibrated to 2620-2470 cal BC and 2470-2290 cal BC (both at $95 \%$ C.I. -see Table 1). These differing date ranges were both obtained from samples of the man's left femur. These date ranges were of particular interest in relation to the style of the accompanying Beaker. This style of pottery has been expected to date from within a century either side of 2200 BC (Ros Cleal and Stuart Needham: pers. comm; also Needham, 2005). The median point of the later radiocarbon date range obtained falls at 2380 $\mathrm{BC}$, predating the appearance of such ceramics in Britain by the best part of a century. The median point of the earlier date range $(2545 \mathrm{BC})$ predates the respective pot style by nearly two and a half centuries. The latest possible point of the later range (at 95\% C.I.) could just overlap with the appearance of Wessex Middle Rhine/ Tall Mid-Carinated Beakers, although this appears highly unlikely given the other date range obtained and ${ }_{2}$ on balance ${ }_{2}$ the two radiocarbon results together are most plausibly interpreted as showing the burial to predate the pot by between one and three (and possibly as much as four) centuries.

\subsection{The Satellite Inhumations}

These individuals were all young, with the exception of F8 who was, at most, a young adult (Table 1). Aside from this last inhumation, which has been severely damaged by ploughing, these skeletons were relatively complete. Levels of preservation vary across each skeleton but are good overall, although fragmentation of several important diagnostic areas and the immature nature of the skeletal remains hinder osteological assessment. Two of the satellite burials, F3 and F4, produced radiocarbon dates of 1620-1500 cal BC and 1500-1390 cal BC, respectively. These are clearly in the Middle Bronze Age and contracted burials of this date were found within a contemporary cemetery placed in the ditch and just outside of the present barrow's nearest known neighbour some 130m to the north on Down Farm (Fig. 1b). This neighbouring barrow, which also only survived as a ring ditch, had a remarkably similar biography to that at Canada Farm, and has been discussed in detail elsewhere (Barrett et al. 1991a, 1991b, Green 2000 and Green in Jones et al. 2012). Radiocarbon dates were not obtained for F5, F6 and F8, although parallels between burial styles suggest them to be roughly contemporary. All five satellite burials were interred in a tightly flexed position, with all recovered bones in their correct anatomical relationships. None were accompanied by any grave goods, conforming to the usual tradition at that time. 
Where there was damage to these skeletons this took the form of root etching and postmortem breaks indicated to have occurred in the burial environment by their irregular course and patinated margins. A series of linear defects with V-shaped profiles were apparent on the right scapular neck of F4, which would appear to be cutmarks. However, their roughened interiors preclude resolution of this by microscopy as internal surface details have been lost. Of further interest, however, is the repeated presence of regular, circular holes located in the epiphyseal and diaphyseal ends of the long bones of skeleton F3 (see Fig. 3). These features measure approximately $9 \mathrm{~mm}$ in diameter and could be seen to penetrate the respective bones to differing depths. There are no signs of bony reaction or remodelling and the margins and interiors of the defects are patinated identically to the rest of the bone. These features are not consistent with any pathological process or recognised form of natural taphonomic change. In light of this point and also the regular shape of each defect, it is concluded that these features could only have been produced by human agency, apparently having been manually drilled in a rotary motion, which would explain their circular form. An apparently similar, but smaller hole (approximately $3 \mathrm{~mm}$ diameter) was present passing through the first metacarpal of F5 (Fig. 4a). The hand and foot bones were well preserved for all skeletons, but this was the only example of such a hole in this area.

It was of particular interest that, whilst all the 'drill cavities' in the long bones were associated with the ends of the bones, not all of the holes located in the shafts had holes in the corresponding epiphyses. For example, there are holes in both ends of the right femur of F3, which only occur on the unfused diaphyseal shaft; the epiphyses have not been similarly modified. In contrast, the distal end of the left femur exhibits a drill hole through the epiphysis, with a slight continuation into the shaft. In order to create these holes the body must have been in a sufficiently advanced state of decomposition to permit access both to the ends of long bones and for the displacement of unfused epiphyses. This skeleton was essentially articulated when uncovered at excavation. All skeletal elements were in normal anatomical juxtaposition including the ribs, spine and hand bones, with the exception of the bones of the feet and the left patella which had undergone some limited displacement (see fig 2c). These latter are held within labile joints, i.e. joints that are unstable when not supported by soft tissues (Knüsel, 2014) and so would normally be subject to some movement as decomposition advances, unless physically constrained by something preventing this. In this position several of the points at which the bones had been drilled were not accessible; ; for example ${ }_{2}$ the right femur lay below the bones of the left lower limb, and the proximal epiphyses of both tibiae covered the points at which the corresponding diaphysis had been drilled. These observations necessitate that not only must parts of the skeleton of this individual have been selectively extracted and modified, but that the respective elements must then have been manually replaced in order to achieve the position and state of articulation in which the remains were finally buried. The body must therefore have been retained in an accessible location for some time after death, rather than simply being buried shortly after the individual had died.

\subsection{Summary}

In summary, both the primary burial and one of the satellite burials show strong indications that the respective individuals were not deposited in their graves immediately after death but were curated for an extended period. The inconsistency between the pottery type interred with the primary burial and the radiocarbon dates obtained from the skeleton show that this 
individual is likely to have died between one and four centuries prior to being finally buried. If these remains had been found in a disarticulated state, this would simply imply the retention of the bones of a long dead 'ancestor'. The degree of articulation in which the burial was encountered, however, can only be explained by the presence of at least some soft tissues (ligaments etc.) meaning that this individual was buried as an 'intact' body rather than a bundle of curated bones. In the case of the satellite burial, F3, again this individual was neither deposited in the ground shortly after death, nor transferred to the grave as a collection of bones after the soft tissues had decomposed, but rather something in between. The absence of grave goods precludes the kind of comparison of differential dating evidence possible for F1, but the apparent treatment of the body implies something more than short-term retention of the remains.

\subsection{Further Analyses}

A series of further analytical methods was applied to the remains of individuals F1, F3 and F4 in efforts to resolve the above anomalies. The methods and results relating to each mode of investigation are given together respectively.

\subsection{Histological Analysis (TB)}

Lower limb long bone shaft fragments from six individuals were submitted for histological analysis of diagenesis using thin--section light microscopy. Transverse thin sections 50-120 microns thick were cut from each sample using a Leica 1600 diamond-saw microtome. Undecalcified and unstained thin sections were mounted onto a glass slide using Entellan (Merck Chemicals). Thin sections were analysed under normal and polarised light using transmitted light binocular microscopes fitted with polarising filters at 25, 40 and 100 times magnification. Histological preservation was assessed using the Oxford Histological Index $(\mathrm{OHI})$ which translates the percentage intact bone microstructure into an ordinal grade ranging from 0 (worst preserved) to 5 (best preserved) (Hedges et al. 1995; Millard 2001). The variable orientation of concentric microscopic bone lamellae produces birefringence under polarised light. Diagenetic loss of bone collagen reduces and eventually obliterates birefringence. Birefringence was assessed here using the Birefringence Index (BI), which records unaffected (1), reduced (0.5) and obliterated (0) birefringence (Jans et al. 2004).

\subsubsection{Results}

All of the Canada Farm specimens were poorly preserved histologically, apart from the sample from F1 (Table 2). Histological degradation was consistent with Hackett's (1981, 250) non-Wedl MFD (bacterial bioerosion) in all cases (Jans et al. 2004). Variation in bacterial bioerosion has been linked to early taphonomic processes which affect the level of putrefactive decomposition undergone by a skeleton (Jans et al. 2004; Nielsen-Marsh et al. 2007; White \& Booth 2014; Booth 2015). Bones retrieved as part of articulated complete skeletons are usually extensively bioeroded, as the immediate burial of an intact corpse protects it from rapid defleshing by scavengers, thereby exposing the skeleton to extensive bacterial soft tissue decomposition. Bacterial bioerosion is more often reduced or absent in disarticulated archaeological bones, as processes which involve the rapid removal of flesh (e.g. excarnation, dismemberment) limit the level of soft tissue decomposition affecting the bone.

The poor histological preservation of the majority of specimens from Canada Farm suggests that they were exposed to high levels of putrefactive bacterial activity, which is usually 
indicative of primary burial. Deposition within a sealed structure would also protect the body from scavengers and reduce the speed of invertebrate-mediated soft tissue loss (Goff 1991; Anderson 2011). However, the lack of experimental histological data makes it difficult to assess whether this represents a valid alternative scenario. The microstructure of the F1 sample was anomalously well-preserved and comparable to fresh bone. This specimen appears to have suffered little, if any, putrefactive decomposition, which is unusual for a bone from a complete articulated adult skeleton (Booth, 2015). Anoxic or waterlogged environments can inhibit decomposition and reduce bioerosion (Turner-Walker \& Jans 2008; Hollund et al. 2012; Booth et al., in press), but these conditions are unlikely to have been prevalent in the local free-draining sediments. Small parts of the F1 bone thin section had been stained dark brown. This kind of staining is thought to be caused by environmental humic substances and is most often found in bone from contexts which included high levels of decomposing organic material (Booth 2015). It is likely that the brown staining within the F1 sample was caused by decomposition products from the surrounding coffin. Although F1 was coffined, permeable wooden coffins rarely impede bodily decomposition or bioerosion in well-drained environments (Booth 2015). The articulation of the F1 skeleton precludes the possibility that it was rapidly defleshed. Mummified bodies are the only ancient articulated human remains whose bones consistently demonstrate low levels of bacterial bioerosion (Booth et al. 2015). Therefore, the best explanation for the anomalous diagenetic signature of the F1 individual is that it was mummified before being buried, in common with skeletons recovered from several British Bronze Age sites (Parker Pearson et al. 2005; 2007; Booth et al. 2015).

\subsection{Experimentation (GD and $M G)$}

To help resolve the question of whether the circular holes observed on F3 and F5 were the result of deliberate anthropogenic modification, attempts were made to replicate them experimentally using contemporaneous types of flint tools. The holes observed on the proximal and distal unfused diaphyses of the right femur of individual F3 and on the distal end of the left first metacarpal of F5 (Figs. 3 and 4) were replicated on the unfused diaphyses of a pig (Sus scrofa) femur and on a pig rib, respectively. Two types of replica flint tools were selected, a borer and an awl, similar to those found during excavations at the nearby Bronze Age site of Monkton-up-Wimborne, Dorset (French et al. 2007). This allowed determination of which type of tool was more appropriate for drilling holes in different experimental bone elements. Using replicas of the awl and the borer, the experimental holes in the pig rib were drilled from both sides until the holes joined, piercing the full thickness of the bone. To assess whether the direction of rotation was important, two different rotating movements were used to drill the holes at the proximal and distal unfused diaphyses of the experimental femur. Using the borer, the experimental hole in the pig proximal femur was drilled using a $360^{\circ}$ unidirectional rotating movement. The hole in the pig distal femur was drilled using a $180^{\circ}$ bidirectional (backward and forward) rotating movement imitating that of a bow drill. Although both the experimental tools used were suitable for drilling holes, the point of the awl was more prone to breaking, and it was felt that, by comparison, the borer is steadier in the hand and could be more adapted to drilling holes in bone. Initial results confirm this hypothesis and determine the borer to be the more appropriate choice. The experimentally drilled holes were then investigated and recorded using the same modalities as used for the archaeological material. It is of course possible that the holes in F3 and F4 were made using metal tools. Artefacts specifically interpreted as piercing tools from this period are all chipped stone objects, hence the choice of replica tools in the experiments. However, 
further work comparing flint with bronze tools for use in drilling bone remains open as an avenue for future experimentation.

\subsection{Electron Microscopy $(G D)$}

Details of the edges and interior of the archaeological and experimentally-drilled holes were examined using a JEOL (JSM-6010 PLUS/LV), scanning electron microscope (SEM). Images were captured at high resolution and at a magnification ranging from $14 \mathrm{x}$ to $27 \mathrm{x}$. The SEM was operated in a variable pressure mode (chamber pressure $15 \mathrm{~Pa}$ ). This allowed for the acquisition of back-scattered electron (BSE) images without applying a conducting layer on the specimen. The parameters for the specimens were set as: accelerating voltage of between $1 \mathrm{kV}$ and $3 \mathrm{kV}$, spot sizes between 55 and 69, and pole-piece to specimen working distance of between $13 \mathrm{~mm}$ and $32 \mathrm{~mm}$. Energy-dispersive $\mathrm{x}$-ray (EDX) microanalysis was carried out using INCA software.

\subsubsection{Results}

Scanning electron microscopy (SEM) of portions of the experimentally-drilled holes on the proximal and distal unfused pig femoral diaphyses, show a regular, slightly serrated edge profile (Fig. 6b, d). A similar profile is observed on the proximal and distal ends of the human right femur (Fig. 6a.) The serrated edges are similar to those reported in SEM studies of perforations made by stone tools (e.g. Olsen 1988) and are consistent with anthropogenic agency in the drilling of the two holes observed in the human femur. On the experimental pig rib, whether drilled with an awl (Fig. 6c) or a borer (Fig. 6d), the SEM results show a regularedged hole (4 $\mathrm{mm}$ and $3.88 \mathrm{~mm}$ in diameter) and internal striae transverse to the longitudinal axis of the defect. Such features are diagnostic of lithic technology as reported by Giacobini and Patou-Mathis (2002) and Olsen (1988). The areas around the lateral and medial holes of the proximal end of the human left first metacarpal are eroded and the bone is root--marked. The results from SEM analysis show an irregularly-_shaped surface $(4.07 \mathrm{~mm}$ long and 3.47 $\mathrm{mm}$ wide) with serrated edges on the medial side of the human left first metacarpal (Figs. 7e, g.). A round-shaped hole (3.21 $\mathrm{mm}$ in diameter), with sections exhibiting regular edges, is observed inside a larger irregularly-shaped surface on the lateral side of the human left first metacarpal. There is no evidence for striae, but the sections of regular edges on the surface of the hole in the lateral side of the metacarpal are similar to those observed on the experimentally-_drilled holes. The more regular appearance of the lateral entrance, as opposed to the more irregular form of the opening on the opposite side, is consistent with the pattern of disruption usually seen in rotary drilling of brittle materials. In such instances the entrance point tends to be more neat and regular whilst the exit point of the drill tends to exhibit 'exit burring'. This is where material is forced outwards from the edges of the drill channel to leave irregular projections in more plastic materials, or to cause irregular sections of material to delaminate and break away as the drill bit emerges on the other side in more brittle materials (Chambers and Bishop, 1995, 571).

\subsection{Micro-CT Scanning $(G D)$}

Micro-computed tomography (micro-CT) was carried out to measure and record the internal dimensions and angles of the holes in the archaeological (human) and experimental (pig) femora and the volume of the holes in the human metacarpal and the pig rib. The specimens were scanned using a HMX ST 225 CT (Nikon Metrology). The instrument uses a cone beam projection system with a four-megapixel detector panel. Different settings were used to 
optimize contrast and minimize the effects of beam hardening. All bones were orientated with their long axis set vertically with respect to the beam to ensure maximum resolution while minimizing streak artefacts ( $\mathrm{Yu}$ et al. 2004). The human femur was reconstructed by combining two CT-scans (proximal to mid shaft and mid shaft to distal). For the human bones, the final scan parameters were: Tungsten target, $180 \mathrm{kV}, 160 \mu \mathrm{A}$, and 3142 projections with 500-milliseconds exposure. The voxel size was of $112 \mu \mathrm{m}$ for the femur and of $16 \mu \mathrm{m}$ for the metacarpal. A $0.1 \mathrm{~mm}$ copper plate was used. The final scan parameters for the pig femur were as follow: Tungsten target, $200 \mathrm{kV}, 180 \mu \mathrm{A}, 3142$ projections with 708 milliseconds exposure, and a voxel size of $89 \mu \mathrm{m}$. A $1 \mathrm{~mm}$ copper plate was used. For the pig rib, these were: Tungsten target, $180 \mathrm{kV}, 160 \mu \mathrm{A}$, and 3142 projections with 500-milliseconds exposure and a voxel size of $22 \mu \mathrm{m}$. A $0.25 \mathrm{~mm}$ copper plate was used. The micro-CT data were reconstructed using CT-Pro software 2.0 (Nikon Metrology) and rendered using Drishti v.2.4 visualisation software.

\subsubsection{Results}

The micro-CT scan data show a U-shaped hole in the proximal pig femur (Fig.7a-c) with regular contours. At the distal end the images reveal a $\mathrm{V}$-shaped hole with irregular contours (Fig. 7d-f). The micro-CT scan of the human proximal femur shows a U-shaped hole with regular contours (Fig. 7g-i). The cross-section of the human distal femur shows a $\mathrm{V}$-shaped hole. The U-shape and wide angle of the pig femur proximal hole was created by a $360^{\circ}$ unidirectional movement being applied. By contrast, using a $180^{\circ}$ bidirectional movement resulted in the V-shape and narrower angle of the pig femur distal hole. Coinciding with two different drilling movements, virtual transverse sections show that the edges of the experimental holes are rough at the distal end, but neat and regular at the proximal end (Fig. $8 a, b)$. The same is true for the human femur, where virtual transverse sections show that the holes are rough at the proximal end, but neat and regular at the distal end (Fig. 8c,d). These comparative results from micro-CT data show the holes in the bones of F3, firstly, to be consistent with having been produced using a single tool and, secondly, to be highly consistent with drilling using a flint borer. The experiences of attempting to reproduce such holes led the individual involved (MG) to also suggest that the choice of drilling method could result from being adapted to the ontogenic shape of the human bone. The conscious choices reported by MG when drilling the experimental holes in the pig femur support this hypothesis.

The experimental drill holes were created for qualitative comparison rather than producing a large sample for comparing repeated measurements. However, metric comparison with the dimensions of the holes in the femur of F3 was not without interest (Table 3 ). The experimental holes were very close in diameter to those in $\mathrm{F} 3$ ( $<5 \%$ difference). In terms of depth and angle the proximal holes exhibit greater differences, but the holes drilled in the distal ends are again extremely similar. This difference may stem from variations in the form of human and pig femora, which differ more from each other at the proximal end than at the distal end. The porous structure of the human metacarpal bone prevented a micro-CT analysis as the air-filled cavities from the bone structure are indistinguishable from those resulting from the hollow left by the 'drill'.

\subsection{Discussion}

The application of a varied suite of techniques to the human remains from Canada Farm has provided multiple lines of complementary data that go beyond the standard range of analyses 
generally applied to archaeological burials. Taken together these additional data allow the unusual aspects of these burials to be considered in greater detail than would otherwise have been possible. They also permit competing hypotheses to be evaluated in terms that are less speculative than they might otherwise be. The two radiocarbon dates obtained from the primary burial F1 appear to show the body to be older than the Beaker with which this individual was buried. There are three interpretations which we regard to be particularly plausible regarding what this means. Firstly, if taken at face value, the discordant dating ranges of the ceramic and radiocarbon assessments, in conjunction with the articulated nature of the skeleton could indicate that a degree of soft tissue remained in place when the body was interred, and that this event took place between one and four centuries after the death of the individual. Perhaps most plausibly such soft tissues might consist of skin and connective tissues (ligaments and tendons particularly) in a desiccated state. For this to occur, the body must have been retained and curated after death, either in circumstances that permitted it to dry out slowly, or with the application of some deliberate means of preserving soft tissues. A second possibility is more mundane, the coffin in which the body was placed was re-opened some considerable time after the death and burial of the individual, and the Beaker was placed inside. The third possibility is that the death of the individual occurred at the very far end of the second radiocarbon date range obtained, which overlaps with the earliest point at which the respective style of Beaker is first known to appear in Britain.

Of these three possibilities, the suggestion most easily discounted is the second on the basis that, had the individual simply been buried around the time of his death, it would not be possible to then open the coffin generations later as it would have been sealed beneath the barrow, rendering it inaccessible. It is of course possible that the barrow could have been dug into to uncover the coffin and permit it to be opened. This scenario seems rather implausible, however, not least as it is reliant on the coffin having resisted decay in the ground over an extended period. The excavator (MG), who is very experienced, noted no signs of any secondary cut into the grave, although the overlying mound could no longer be observed as it had been ploughed away. Furthermore, we know of no archaeological parallels for such from this period, with the possible exception of the burial of Gristhorpe Man (Melton, et al., 2013). Here a layer of oak branches overlying an oak log coffin containing an elaborate Early Bronze Age burial sealed beneath a barrow, has produced a radiocarbon date that lies between 270 and 670 years after the man's death. However, the lack of detail in the records of the excavation (conducted in 1834) means that it is not possible to say whether the placement of the branches involved digging into the barrow or rather occurred as part of a second phase of construction where the original mound was added to rather than invasively disturbed. Alternatively, if the Canada Farm coffin had not been placed in the grave and covered by the barrow until a time contemporaneous with the Beaker, then this returns the picture to one of retention of a dead 'ancestor' for a protracted period. We would argue that, given the overall evidence, this seems more plausible than the barrow undergoing excavation in the Beaker period. The fact that the dates provided by ceramic typology and radiocarbon dating could overlap at their extreme ranges remains a possible solution. However, this latter hypothesis fails to explain the initial radiocarbon result (2620-2470 cal BC). Whilst one of the AMS results obtained must be closer to the real age of the bone tested than the other, it is ultimately more likely that the answer lies somewhere in between the two, rather than completely outside one range and at the extreme latter end of the other. A point that does remain troubling is the fact that ${ }_{2}$ at $95 \% \mathrm{CI}_{2}$ the two $\mathrm{C}^{14}$ dates do not overlap each other. This raises the question of whether some diagenetic aspect of the way the body was preserved has affected one or both of the radiocarbon dates.? As mentioned above (section 3.1.1), the histological analysis also revealed brown--stained inclusions in the bone which may relate to 
decayed coffin material that had made its way into the bone cortex. If such inclusions had a variable effect on the radiocarbon dating this might explain why different dates were obtained from the same bone, although it would present challenges in determining which date is most correct.

A further typological point to consider is the dating of coffined burials. As the presumed coffin at Canada Farm was only evidenced by its profile at the base of the grave it is not possible to say whether it was plank--built or carved from a single log. If it was the latter these appear in several regions of Britain, including a prominent cluster in Wessex, as part of a wider range of elaborate burial practices around the beginning of the Early Bronze Age. Parker Pearson et al. (2013) list nine log coffin burials for which reliable dates are available. The size of these date ranges varies, but the median points of all nine fall after $2300 \mathrm{cal} \mathrm{BC}$ (95\% CI) of which one is between 2201 and 2300 cal BC, three are between 2101 and 2200 cal BC, one between 1901 and $2000 \mathrm{cal} \mathrm{BC}$ and the remaining three between 1801 and 1900 cal BC. If buried in a similar style of coffin, the Canada farm example could therefore be argued to likely post-date the radiocarbon age of the skeleton to at least a similar degree to the style of the Beaker, although this point remains speculative as the possibility of an earlier style plank_-built coffin cannot be excluded.

Turning to an alternative line of evidence, the histological analysis was conducted with a view to establishing whether the respective bones displayed patterns of degradation of the kind normally produced in putrefactive decay or whether they exhibited signatures that differed from this. As outlined above the bone from F1 was remarkably well-preserved to the extent that it retained its normal microstructure in similar proportions to that of fresh bone. The only way that this can have been achieved is if the normal processes of putrefaction were prevented from occurring. The principal source of putrefactive bacteria in a corpse is the gut flora of the dead person. This causes the abdominal contents to putrefy first, with decomposition then spreading outwards to affect progressively more peripheral parts of the body. Chalcolithic and Bronze Age people would have been familiar with methods of butchering animals and would undoubtedly have known that the flesh lasts much longer when the abdominal contents are removed. If this principle had been applied to a deceased person, with the body then bound or wrapped and kept in a warm, dry environment such as within a house, it is plausible that the remaining soft tissues could desiccate, whilst the bones would remain well-preserved as is the case for F1. Other suggestions for means of deliberate preservation available to Bronze Age people include smoking or deposition in a peat bog (Booth et al., 2015). The latter option would have been unavailable in the Cranborne Chase environs, whilst none of the bones or teeth of F1 display discolouration consistent with prolonged exposure to smoke, and so evisceration followed by wrapping currently seems the most plausible option.

Turning to the anthropogenic modifications in the bones of two of the Middle Bronze Age burials (F3 and F5) apparent as circular channels produced by drilling, these are by definition indicative of the retention of these bodies, (F3 in particular), for some time after death. The sites at which the drill holes in F3 are located would not be accessible whilst the soft tissues were present. Even once soft tissue decomposition had largely run its course it would not be possible to access several of the drilled areas without disarticulating the respective joints. Given that F3 was buried in full articulation in a flexed position, it must therefore be concluded that, after the respective joints had been drilled, the remains of this individual were manually re-assembled before the body was finally interred in the barrow ditch. This observation raises the question of what practical purpose (if any) such modification of these bones might serve? Archaeological parallels for such are limited. Whilst trepanation is widely 
known from later prehistory (Arnott et al., 2003), the drilling of human bones from other parts of the skeleton has rarely been observed. An apparent example from Britain is that of an articulated Bronze Age burial excavated at Over (Cambridgeshire) in which the right ulna had a circular full thickness defect similar in appearance to the Canada Farm 'drill holes' (Chris Evans pers. comm.). Other examples are widely separated in space and time from Bronze Age Wessex and also differ in social context such as drilled human forearms removed as war trophies in prehistoric California (Andrushko et al., 2005). The drilling of human crania for suspension and display is known from pre-hispanic Peru (Andrushko, 2011), but again relates to trophy-taking rather than to funerary practice. What would appear to be the closest parallel to the Canada Farm examples was noticed when an Egyptian mummy was examined radiographically in 1995 (Greenhagen et al., 2011). The mummy was discovered in the sarcophagus of a New Kingdom priest named as Usermontu, although it would appear that the sarcophagus had later been reused and the actual identity of the mummy is unknown. Here an iron pin had been inserted into the right femur and tibia to hold the knee joint together, some time between death and mummification, presumably to ensure the individual arrived with the limb intact in the afterlife.

A possible explanation for the drilled bones at Canada Farm is that, like the Egyptian example cited above, the holes might have originally held some sort of manufactured object with a circular profile such as a peg or dowel. Toggles made of worked bone or antler with a circular profile, of similar diameter to the F3 drill holes are certainly known from Bronze Age Britain (Piggott, 1958, Gardiner et al., 2007, Hunter and Woodward, 2014, 121, Fitzpatrick, 2013, pl.18) not to mention that one was found among the grave goods of F1. If such objects were originally present in the drill holes but were made of other organic material (most likely wood) these would have decayed relatively quickly once buried. If the holes were indeed made to hold pegs or dowels, these might in turn be attached to each other, perhaps using cord or leather, which would have had the effect of artificially keeping the respective limbs/joints attached to the rest of the body. Such an arrangement implies a desire to maintain the remains of an individual in normal articulation as an 'intact' body for some time after death. If the body of F3 was retained and curated as would appear to be the case for F1, the continued existence of the body in an articulated state would have required a degree of soft tissue preservation, otherwise the limbs would disarticulate naturally over time. The results of histological analysis for F3 are consistent with the pattern that would be expected from the normal course of decomposition. It would seem therefore that, whatever circumstances in which the remains of $\mathrm{F} 3$ were retained, these were not sufficient to prevent the normal processes of decay. If this was the case, then the use of pegs/dowels to fix the limbs to the rest of the body would make sense as a practical solution to keep the body together as it began to fall apart naturally, effectively imitating a better preserved body such as that of F1. At the point when both F3 and F5 were interred they would have appeared to have been bound in the tightly flexed position observed at excavation, perhaps having been deposited as wrapped bundles.

Ethnographic examples of the retention of the dead following some form of anthropogenic mummification are known from various parts of Southeast Asia and the Pacific. Such practices include smoking, wrapping and also the evisceration of the dead to effect soft-tissue preservation. In particular the Sa'dan Toraja of South Sulawesi (Indonesia) retain the bodies of high--status individuals for extended periods (Weiss-Krecji, 2012), in order to permit bodies to be repeatedly exhumed from coffins and given new clothes. If the retained bodies of F3 and F5 were kept as wrapped bundles with the body tightly flexed within, these might have been similarly unwrapped periodically. Such unwrapping (or alternatively periodic or even ongoing display) of the body could have permitted the realization that F3 had decayed 
to the point where the limbs were coming apart, prompting the decision to fix the failing joints back together again using wooden dowels. If F3 in particular had been surrounded by wrappings when buried this would also have allowed some space within the grave for labile joints to move slightly. This possibility could explain the movement seen in the foot bones and patellae which would have been prevented from moving if encased by direct contact with the soil matrix of the grave fill immediately at burial.

The central inhumation (F1) and the surrounding satellite burials are separated by several centuries. Other than for the fact that the later inhumations were placed in close proximity to the same burial monument, there would be no particular reason for discussing them here in the same article. However, when the various anomalous features of these burials, particularly F1 and F3, are considered together, they both exhibit evidence for the retention of human remains in an articulated state for an extended period of time before their final inhumation. In this respect the separation in time of these burials is of particular interest because it implies that such a tradition may have lasted for several centuries from at least the earlier Chalcolithic to the Middle Bronze Age. Such a suggestion would then be of interest in itself as a phenomenon local to the Cranborne Chase region of central southern Britain, but can be argued to have much greater significance in light of previous claims for evidence of such practices in other regions of Britain during the Bronze Age.

Parker Pearson and colleagues $(2005,2007)$ have recorded articulated Late Bronze Age burials from the Western Isles (Scotland) that must have been curated with preserved soft tissues holding them together for extended periods before they were finally buried. Booth's (2015) subsequent study (also Booth et al. 2015) of histological preservation in 301 individuals from a wide range of archaeological burials, mostly from Britain, demonstrates that the majority of this sample, particularly those from historic contexts, exhibit levels of bioerosion consistent with burial soon after death. However, just under half of the Bronze Age burials analysed (16/34) display high levels of bone preservation consistent with that seen in mummified remains. It would seem, therefore, that one or more forms of mortuary practice were apparently widespread during the British Bronze Age in which the preservation of the dead with soft tissue remaining was the desired aim. Attempts at such preservation may, in fact, have met with variable success, as illustrated by the poor preservation and implied natural disarticulation of Canada Farm F3, with subsequent attempts to maintain the body in articulation by artificial means. The current analyses of the Canada Farm remains are of further significance in this respect, firstly in extending the temporal spread of such treatments back to the earlier Chalcolithic (the earliest Beaker period in Britain), whilst also extending the geographical range of this practice to the south of Britain. If mummification was practised in the far north of Britain, as indicated by the Cladh Hallan find (Parker Pearson et al., 2005, 2007) and also at the far south, as apparent at Canada Farm, then it is reasonable to suggest that such traditions are likely to have existed in other parts of the British Isles spanning the regions in between.

\section{Acknowledgements}

We are grateful to Peter Andrews and Sylvia Hixson-Andrews for sharing their insights on the taphonomy of the assemblage, Dan Sykes and Rebecca Summerfield for providing training and assistance with micro-computed tomography, Paola Barbuto for SEM training, Rob Read (for the illustrations), and Mike Henderson for the pottery reconstruction and conservation. We also thank Ros Cleal and Stuart Needham for sharing their insights on the 
style and date of the Beakers. The thin-section histological analysis of bone was carried out at the University of Sheffield Department of Archaeology. The geophysical surveys were undertaken by Bournemouth University students as part of their undergraduate BSc Archaeology programme.

\section{References}

Anderson G.S. (2011) "Comparison of decomposition rates and faunal colonisation of carrion in indoor and outdoor environments” Journal of Forensic Sciences 56,136-142.

Andrushko, V.A. (2011) "How the Wari fashioned trophy heads for display: a distinctive modified cranium from Cuzco, Peru, and comparison to trophies from the capital region" in: Bonogofsky, M. (ed.) The Bioarchaeology of the Human Head: Decapitation, Decoration, and Deformation Gainesville (FL), Florida University Press, 262-285.

Andrushko, V.A., Latham, K., Grady, D.L., Pastron, A.G., Walker, P.L. (2005)

"Bioarchaeological Evidence for Trophy-Taking in Prehistoric Central California" American Journal of Physical Anthropology 127, 375-384.

Arnott, R., Finger, S. and Smith, C. (eds.) (2003) Trepanation: History, Discovery, Theory Lisse: Swets \& Zeitlinger.

Barrett, J., Bradley, R. and Green, M. (1991a) Landscape Monuments and Society: the Prehistory of Cranborne Chase Cambridge: Cambridge University Press.

Barrett, J.C., Bradley, R. and Hall, M. (eds.) (1991b) Papers on the Prehistoric Archaeology of Cranborne Chase. Oxford: Oxbow 11.

Binford, L.R. (1981) Bones, Ancient Men and Modern Myths. London: Academic Press.

Booth, T.J. (2015) "An investigation into the relationship between funerary treatment and bacterial bioerosion in European archaeological bone" Archaeometry (early view online: DOI: 10.1111/arcm.12190).

Booth, T.J. Chamberlain, A.T. and Parker Pearson, M. (2015) "Mummification in Bronze Age Britain" Antiquity 89, 1155-1173.

Chambers, A. and Bishop, G. (1995) "The drilling of carbon fibre polymer matrix composites" in: Poursartip, A. and Street, K. (eds.) Proceedings of the Tenth International Conference on Composite Materials, Volume III: Processing and Manufacturing Cambridge: Woodhead Publishing, 565-572.

Drishti (version 2.4) Volume Exploration and Presentation Tool. Available from: http://anusf.anu.edu.au/Vizlab/drishti / (accessed May 2014).

Fitzpatrick, A. (2013) The Amesbury Archer and the Boscombe Bowmen - Bell Beaker burials at Boscombe Down, Amesbury. Salisbury: Wessex Archaeology, Report No. 27. 
French, C., Lewis, H., Allen, M.J., Green, M., Scaife, R. and Gardiner, J., 2007. Prehistoric landscape development and human impact in the upper Allen valley, Cranborne Chase, Dorset. Cambridge: Macdonald Institute for Archaeological Research.

Gardiner, J., Allen, M.J., Powell, A.B., Harding, P., Lawson, A.J., Loader, E., McKinley, J.I., Sheridan, A. and Stevens, C.J. (2007) "A Matter of Life and Death: Late Neolithic, Beaker and Early Bronze Age Settlement and Cemeteries at Thomas Hardye School, Dorchester" Proceedings of the Dorset Natural History and Archaeological Society 128, 17-52.

Giacobini, G. and Patou-Mathis, M. (2002) "Fiche rappels taphonomiques" in: Patou-Mathis, M. (ed.) Industrie de l'os préhistorique, Cahiers X. Compresseurs, Percuteurs, Retouchoirs Paris: Editions Société Préhistorique Française, 21-28.

Goff, M.L. (1991) "Comparison of insect species associated with decomposing remains recovered from inside dwellings and out-doors on the Island of Oahu, Hawaii" Journal of Forensic Sciences 36:748-753.

Green, M. (2000) A Landscape Revealed: 10,000 Years on a Chalkland Farm. Stroud (U.K.): Tempus.

Green, M. (2012) "Cursus continuum: further discoveries in the Dorset Cursus environs, Cranborne Chase, Dorset” In: Jones, A.M., Pollard J., Allen M.J. and Gardiner J. (eds.) Image, Memory and Monumentality, Archaeological Engagements with the Material World. Prehistoric Society Research Paper 5.

Green, M. and Allen, M.J. (1997) "An early prehistoric shaft on Cranborne Chase" Oxford Journal of Archaeology 16, 121-32.

Greenhagen, R., Johnson, A. and Joseph, A. (2011) "Internal fixation: a historical review" clinics in Podiatric Medicine and Surgery 28, 607-618.

Hackett C.J. (1981) "Microscopical focal destruction (tunnels) in exhumed human bones" Medical Science and Law 21, 243-266.

Haglund, W. (1997) "Dogs and Coyotes: post-mortem involvement with human remains" in: Haglund, W. and Sorg. M. (eds.) Forensic Taphonomy: the Postmortem Fate of Human Remains London: CRC Press.

Hedges R.E.M., Millard A.R., Pike A.W.G. (1995) "Measurements and relationships of diagenetic alteration of bone from three archaeological sites" Journal of Archaeological Science 22, 201-209.

Hollund H.I., Jans M.M.E., Collins, M.J., Kars, H., Joosten, I., Kars, S.M. (2012) "What happened here? Bone histology as a tool in decoding the postmortem histories of archaeological bone from Castricum, The Netherlands" International Journal of Osteoarchaeology 22,537-548.

Hunter, J. and Woodward, A. (2014) Ritual in Early Bronze Age Grave Goods. Oxford: Oxbow. 
Jans MME, Nielsen-Marsh CM, Smith CI, Collins MJ. \& Kars H. 2004. Characterisation of microbial attack on archaeological bone. J Archaeol Sci 31:87-95.

Knüsel, C.J. (2014) "Crouching in fear: terms of engagement for funerary remains" Journal of Social Archaeology 14, 26-58.

Melton, N., Montgomery, J. and Knüsel, C. (eds.) (2013) Gristhorpe Man: A Life and Death in the Bronze Age Oxford: Oakville.

Millard A. (2001) "The Deterioration of Bone” In: Brothwell, D. and Pollard, A.M. (eds.) Handbook of Archaeological Sciences. Chichester: John Wiley \& Sons, 637-647.

Needham, I.S. (2005) "Transforming Beaker culture in North-West Europe; processes of fusion and fission” Proceedings of the Prehistoric Society 71, 171-217.

Nielsen-Marsh, C.M, Smith, C.I, Jans, M.M.E., Nord, A., Kars, H. and Collins, M.J. (2007) "Bone diagenesis in the European Holocene II: Taphonomic and environmental considerations" Journal of Archaeological Science 34, 1523-1531.

Olsen, S.L. (1988) "The identification of stone and metal tool marks on bone artifacts" in: Olsen, S.L. (ed.) Scanning Electron Microscopy in Archaeology. BAR International Series 452, 337-363.

Parker Pearson, M., Chamberlain, A., Craig, O., Marshall, P., Mulville, J., Smith, H., Chenery, C., Collins, M., Cook, G., Craig, G., Evans, J., Hiller, J., Montgomery, J., Schwenninger, J., Taylor, G. and Wess, T. (2005) "Evidence for mummification in Bronze Age Britain" Antiquity 79, 529-546.

Parker Pearson, M., Chamberlain, A.T., Collins, M.J., Cox, C., Craig, G., Craig, O.E., Hiller, J., Marshall, P., Mulville, J. \& Smith, H. 2007. Further evidence for mummification in Bronze Age Britain. Antiquity http://antiquity.ac.uk/ProjGall/parker312/html.

Parker Pearson, M., Richards, M., Chamberlain, A. and Jay, M. (eds.) (in press) The Beaker People: isotopes, mobility and diet in prehistoric Britain. Prehistoric Society monograph. Oxford: Oxbow.

Parker Pearson, M., Sheridan, A. and Needham, S. (2013) "Bronze Age tree-trunk coffin graves in Britain" in: Melton, N., Montgomery, J. and Knüsel, C. (eds.) (2013) Gristhorpe Man: A Life and Death in the Bronze Age Oxford: Oakville, 29-66.

Piggott, S. (1958) "Segmented bone beads and toggles in the British Early and Middle Bronze Age" Proceedings of the Prehistoric Society 24, 227-9.

Smith M.J. (2006) "Bones chewed by canids as evidence of human excarnation: a British case study" Antiquity 80, 1-15.

Turner-Walker, G. and Jans, M. (2008) "Reconstructing taphonomic histories using histological analysis" Palaeogeography, Palaeoclimatology, Palaeoecology, 266, 227-235. 
Weiss-Krecji, E. (2012) "Shedding light on dark places: deposition of the dead in caves and cave-like features in Neolithic and Copper Age Iberia" in: Bergsvik, K.A., Andreas, K., Bergsvik, S. and Skeates, R. (eds.) Caves in Context: The Cultural Significance of Caves and Rockshelters in Europe Oxford: Oxbow, 118-137.

White, L. and Booth, T.J. (2014) "The origin of bacteria responsible for bioerosion to the internal bone microstructure: Results from experimentally-deposited pig carcasses" Forensic Science International 239, 92-102.

Yu, Z., Sidky, E.Y. and Pan, X. (2004) "Partial volume and aliasing artefacts in helical conebeam CT" Physics in Medicine and Biology, 49, 2365-2375. 


\section{Figure Captions}

Figure 1. Area of the Canada Farm 2009 excavations, a. Location of Cranborne Chase in Southern England; b. Location plan showing the near relationships of Martin Green's excavations North of the Dorset Cursus*; c. Fluxgate gradiometry Geoscan Research FM36, reading interval: $0.25 \times 1 \mathrm{~m}$, high pass filtered, black = positive, $\mathrm{d}$. plan of the CF09 ring ditch and associated burials* (*drawings by Rob Read).

Figure 2. a. view of the excavation to the north east, b. the central interment (F1), the cut for the 'coffin' can clearly be seen; c. satellite burial F3; d. satellite burials F4 and F5 uncovered in the secondary ditch terminal; e. The Beaker from the central inhumation (F1) left, and the small Beaker from F2 after conservation by Mike Henderson.

Figure 3. The excavated bones of burial F3 (probable female, approx. 12-13 yrs) with locations of regular circular defects (insets) positioned at a. right proximal femoral diaphysis; b. right distal femoral diaphysis; c. right proximal tibial diaphysis; d. apparent similar hole (now taphonomically damaged) in left proximal humeral diaphysis; e. transverse hole piercing lateral margin of left distal femoral diaphysis; f. left distal femoral epiphysis; g. left proximal tibial diaphysis.

Figure 4. a. $1^{\text {st }}$ Metacarpal of F5 showing circular defect traversing the bone; b. and c. Experimental drill holes in animal bone and replica tools used; flint borer and drilled pig proximal femoral diaphysis (b.); flint awls, borer and drilled pig rib (c.).

Figure 5. Optical microscopic view (magnified x100) of histological section of bone sample from the left femur of the central inhumation (F1). The bone microstructure is extremely well preserved with very little erosion from bacterial tunnelling. This level of preservation would normally be expected only in fresh bone or in mummified remains.

Figure 6. Scanning Electron Micrographs comparing the interior topography of the Canada Farm 'drill holes' with experimental holes drilled in pig bones; a. Margin of defect in human femoral diaphysis looking down into the hole; $b$. Margin of drilled hole in pig femoral diaphysis in the same view; c. Hole drilled in pig rib using awl; d. Hole drilled in pig femur using borer; e. and f. 'entry' and 'exit' points of the hole in MC1 of F5; g. and h. the same two views with the overall area of the defect highlighted. The defect is smaller and neater on the 'entry' side (e., g.) with a clear circular profile retained around portions of its perimeter. On the 'exit' side (f., h.) the defect is ragged and irregular consistent with the 'burr' effect usually seen in directional drilling of brittle materials, in this case the drilling would have been effected from the lateral to the medial side of the bone.

Figure 7. Micro-CT images of the experimental holes drilled in the pig femur and the holes observed in the femur of burial F3; a.-c. section through pig, proximal femur showing longitudinal profile (a.), measurement of depth (b.) and angle (c.) of drilled hole; d-f. section through pig distal femur showing longitudinal profile (d.), measurement of depth (e.) and angle (f.) of drilled hole; g-i. section through human (F3) proximal femur showing longitudinal profile (g.), measurement of depth (h.) and angle (i.) of defect; j.-l. section 
through human (F3) distal femur showing longitudinal profile (j.), measurement of depth (k.) and angle (1.) of defect, the dense 'white' object visible at the top of these views appears to be a taphonomic inclusion from the chalk soil matrix that had made its way in whilst the bone was in the ground.

Figure 8. Virtual cross sections (CS) through the pig and human (F3) femora produced from CT scan data at the entrance, midpoint and base of each of the drill holes; a. proximal pig femur; b. distal pig femur; c. proximal human femur; d. distal human femur. 


\section{Tables}

Table 1. Inhumation burials in and around the Canada Farm ring ditch (CF09) with radiocarbon results.

\begin{tabular}{|c|c|c|c|c|c|c|}
\hline $\begin{array}{c}\text { Burial } \\
\text { No. }\end{array}$ & Location & $\begin{array}{l}\text { Age } \\
\text { (yrs) }\end{array}$ & Sex & Lab Ref. & AMS Result & $\begin{array}{c}\text { Calibrated Date } \\
(\text { C.I. 95\%) }\end{array}$ \\
\hline \multirow{2}{*}{$\mathrm{F} 1$} & \multirow{2}{*}{$\begin{array}{l}\text { Primary Burial } \\
\text { centre of barrow }\end{array}$} & \multirow{2}{*}{$25-30$} & \multirow{2}{*}{ M } & NZA-34641 & $4091+/-25 B P$ & $2620-2470 \mathrm{cal} \mathrm{BC}$ \\
\hline & & & & SUERC-32210 & $3900+/-30 \mathrm{BP}$ & $2470-2290 \mathrm{cal} \mathrm{BC}$ \\
\hline $\mathrm{F} 3$ & $\begin{array}{l}\text { Grave cut SE of ring } \\
\text { ditch }\end{array}$ & $12-13$ & $? \mathrm{~F}$ & NZA-34642 & $3275+/-20 \mathrm{BP}$ & $1620-1500 \mathrm{cal} \mathrm{BC}$ \\
\hline $\mathrm{F} 4$ & \multirow{2}{*}{$\begin{array}{l}\text { SE ditch terminal of } \\
\text { Phase } 2 \text { ditch }\end{array}$} & $18-19$ & M & NZA - 34643 & $3157+/-25 \mathrm{BP}$ & $1500-1390 \mathrm{cal} \mathrm{BC}$ \\
\hline F5 & & $10-12$ & $? \mathrm{M}$ & & & \\
\hline F6 & $\begin{array}{l}\text { Phase } 2 \text { ditch SE } \\
\text { from centre }\end{array}$ & $3-4$ & $? \mathrm{~F}$. & & & \\
\hline $\mathrm{F} 8$ & $\begin{array}{l}\text { Grave cutting S. } \\
\text { terminal Phase } 1 \\
\text { ditch }\end{array}$ & $17-25$ & Ind. & & & \\
\hline
\end{tabular}

Table 2. Results of the histological analysis of the Canada farm thin sections.

\begin{tabular}{|c|c|c|c|c|c|}
\hline Specimen & Element & $\begin{array}{c}\text { \% Remaining } \\
\text { Microstructure }\end{array}$ & OHI & BI & Bioerosion \\
\hline F1 & Femur & $>95 \%$ & 5 & 1 & Absent \\
\hline F3 & Tibia & $<50 \%$ & 2 & 0.5 & Non-Wedl MFD \\
\hline F4 & Tibia & $<5 \%$ & 0 & 0 & Non-Wedl MFD \\
\hline F5 & Tibia & $<5 \%$ & 0 & 0 & Non-Wedl MFD \\
\hline F6 & Femur & $<5 \%$ & 0 & 0 & Non-Wedl MFD \\
\hline F8 & Lower limb & $<5 \%$ & 0 & 0 & Non-Wedl MFD \\
\hline
\end{tabular}


Table 3. Measurements and comparison of dimensions and angles of experimental holes drilled in the pig femur and holes observed in the right femur of burial F3.

\begin{tabular}{|c|c|c|c|}
\hline \multirow{2}{*}{} & \multicolumn{3}{|c|}{ Proximal Diaphysis } \\
\cline { 2 - 4 } & Human (F3) & Pig & \% Difference \\
\hline Diameter (mm) & 103 & 104 & $0.97 \%$ \\
\hline Depth (mm) & 119 & 90 & $27.75 \%$ \\
\hline Angle & $40.20^{\circ}$ & $61.94^{\circ}$ & $42.57 \%$ \\
\hline Diameter (mm) & 101 & 104 & $2.93 \%$ \\
\hline Depth (mm) & 171 & 167 & $2.37 \%$ \\
\hline Angle & $30.27^{\circ}$ & $30.31^{\circ}$ & $0.20 \%$ \\
\hline
\end{tabular}

